\title{
Hervormde Barthiaanse Skrifbeskouing
}

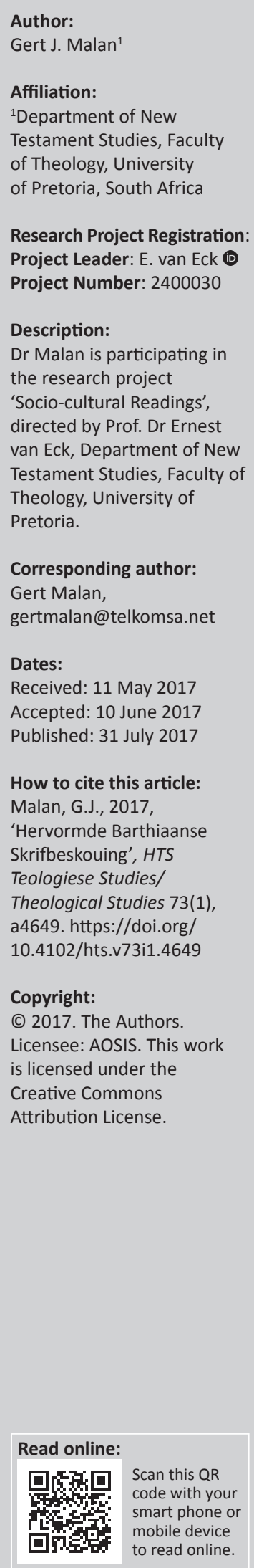

This article constitutes a summary of the development of a unique Barthian blend of Reformed Scripture view by theologians of the faculty of the Netherdutch (Hervormde) Church of Africa. The influence of Barth's Scripture view is discussed according to central themes which were further developed, namely Word of God, revelation, faith, inspiration, authority of Scripture and the relation of the Old to the New Testament, and how these developed. The article concludes that the 'Hervormde' blend of Barthian view of Scripture is a gem to be treasured and guarded against un-Reformed authoritarian fundamentalism and foundationalism.

\section{Inleiding}

Die fokus val in hierdie artikel op die ontwikkeling van Hervormde Skrifbeskouing soos verwoord in publikasies van dosente aan die Teologiese Fakulteit se departemente Godsdiensen Sendingwetenskap, Dogmatiek, Ou- en Nuwe Testamentiese Wetenskap in die mondstuk van Hervormde teologie, naamlik die HTS Teologiese Studies. ${ }^{1}$ Die Bybelwetenskappe se benadering was minder rigied (dogmaties) vanweë die ontwikkeling van eksegetiese metodes van grammaties-histories (etimologies) na histories-kritiese (diakronies), na strukturalisme en lesersgeoriënteerde (sinkroniese) benaderings wat uitgeloop het op die kombinasie van sinkronie en diakronie met die sosiaal-wetenskaplike benadering. ${ }^{2}$ Die aanpak van die artikel is egter nie histories en kronologies nie, ${ }^{3}$ maar volg sentrale temas van Barth se Skrifbeskouing soos deur Van Zyl belig. ${ }^{4}$

\section{Die invloed van Karl Barth}

Die dialektiese teologie van Karl Barth het waarskynlik die grootste invloed gehad op die Hervormde Skrifbeskouing (Breytenbach 1989:329). Prof. F.J. van Zyl [1944] se artikel oor Karl Barth se Skrifbeskouing reeds in HTS Teologiese Studies, Jaargang 1, Volume 3, bevestig dit. ${ }^{5}$ Van Zyl se aanpak kom neer op 'n waarderende instemming met Barth se Skrifbekouing, buiten kritiek op Barth se standpunt oor die onafgeslotenheid van die kanon (Van Zyl 1944:134). In 'n tyd toe 'n prekritiese fundamentalistiese Skrifgebruik algemeen gangbaar was in die Afrikaanse kerke en teologie, het Van Zyl se publikasies oor Skrifbeskouing die moderne Bybelwetenskap in 'n groot mate geantisipeer en verdiskonteer (Van der Merwe 1989:242; ook Geyser 1989:253-262). Ongelukkig het sommige dosente aan die fakulteit by die pre-kritiese en letterlike Skrifbeskouing vasgesteek en onder hulle invloed handhaaf sommige predikante dit steeds.

Hierdie artikel reflekteer die kritiese omgang met en verruiming van Barth se Skrifbeskouing, wat ontwikkel tot 'n eiesoortige Hervormde weergawe daarvan.

\section{Woord van God}

Volgens Barth is die drie gestaltes van die Woord: Openbaring, Skrif en verkondiging, onlosmaaklik verbonde. Die Openbaring is Jesus Christus as God se eie, onbemiddelde spreke in die geskiedenis

1.HTS Teologiese Studies Volume 1 het in 1943 verskyn en Volume 3 in 1944. Hierdie artikel dek dus nie die afgelope 100 jaar nie en ook nie ander kerklike dokumente soos sinodale notules, verslae, kategeseboeke en Bybelstudiehandleidings of artikels in kerklike tydskrifte nie.

2.Hierdie verloop hang natuurlik saam met die oorgang van die modernisme tot die na-modernisme.

3.Om die rubrieke van Barth se Skrifbeskouing en die ontwikkeling daarvan binne die geskiedenisverloop van eksegetiese metodes, die beweging van modernisme na na-modernisme, die politieke geskiedenis in Suid-Afrika en die teologiese fakulteit se geskiedenis aan te dui, sou te omvangryk wees. Die skrywer veronderstel dat lesers met hierdie agtergrond vertroud is.

4.Om hierdie rede word daar ook verwys na teoloë van verskillende departemente aan die fakulteit, sonder om die departemente weer te vermeld. Verder kan lesers aan die hand van publikasiedatums aflei of uitsprake plaas $n$. a.v. ontwikkeling van eksegetiese metodiek, modernisme of na-modernisme en die politieke ontwikkeling in Suid-Afrika en die Nederduitsch Hervormde Kerk van Afrika.

5.Opmerklik dat in Volumes 2 en 3 van HTS een artikel verskyn van prof. S. P. Engelbrecht (1944a; 1944b; 1944c) oor die Nederlandse Geloofsbelydenis as simboliese geskrif en in Volume 4 een oor die Heidelbergse Kategismus as kerklike simbool (my kursivering). Hierdie simboliese aard van die belydenisskrifte dui daarop dat die Hervormde teologie dit op ' $n$ ander vlak beskou as die Bybel, die norma normans. In HTS Volume 1 No. 4 verskyn 'n artikel van prof. Gemser (1944:178-186) oor Luther se siening van die noodsaak om Latyn, Grieks en Hebreeus te leer. Kennis van die brontale was deurentyd belangrik geag in die Hervormde benadering tot Bybeltekste. 
as eenmalige, beslissende gebeure. Die Bybel bestaan uit menslike pogings om in verskillende historiese kontekste hieroor te getuig (Van Zyl 1944:124-125). Daarby word die Bybel op drie vlakke gebruik: as boek van die teologie, van gelowige lidmate en van die kerk. Die Bybel is dus geïnterpreteerde Skrif en daarom nie openbaring self nie net die getuienis daarvan (Van Aarde 2012). Tereg meen Buitendag (2008:1150) saam met Barr dat Barth '... te ver gegaan het om die Woord drievoudig te verstaan: slegs die geïnkarneerde Woord is die openbaring van God - die ander is getuienis'.

Die Kerk verklaar volgens Barth die Bybel as Heilige Skrif, met die verwagting dat dit opnuut vir ons Woord van God kan word. Die Skrif se menslike woorde word vir ons Woord van God wanneer ons dit hoor as God se aanspraak op ons lewens. Die mensewoorde van die Skrif getuig van die Andere, nie oor mense se verhouding met die Andere of hulle Godservaring nie (Van Zyl 1944:126-127). Hierdie gedagte van Barth ondergaan verandering. Die moontlikheid van God se spreke tot ons voer Buitendag (na aanleiding van Jenson) terug na God se wese wat in dialoog met God self is: Jesus Christus is die adres van God se immanente ontologiese dialoog. So word God se gesprek met ons moontlik. Danksy Christus as God se spreke in die geskiedenis, oftewel Christus as die Spreker van God se spreke, kan die kerk as geloofsgemeenskap in die Christus-spreke ook met God praat en so antwoord op God se spreke met ons (Buitendag 2008:1133, 1148).

Die Bybel as Woord van God is, so meen Barth, soos Jesus Christus ware God en ware mens, maar nie in die sin van persoonseenheid of vermenging tussen God en die Bybelse getuies nie. Die Woord van God kan daarom nie van die geskrewe teks van die Bybel losgemaak word nie (Van Zyl 1944:128). Teen hierdie analogie het daar later reaksie gekom, veral omdat die ontstaansproses van die onderskeie Bybelse dokumente nie verreken word nie en dus vra na die verhouding tussen God se werk en menslike handelinge in die wêreld (Breytenbach 1989:329).

God self is vir Barth die handelende subjek in sy Woord, die auctor primarius. God is vrye subjek, nie aan die Woord gebonde nie, maar die Woord aan God. God kan sy Woord gebruik of nie; dit so gebruik of anders, ook met die verkondiging as spreke van God. Dit is die vryheid van die Woord en tegelyk die trou van God aan die Kerk, waardeur God self voortdurend na ons toe kom (Van Zyl 1944:129-130). Buitendag (2008:1141) voeg by: Die Skrif self het geen intrinsieke metafisiese kwaliteit nie. Die primum principium is alleen God wat genadig na ons uitreik en sodanig deur gelowiges beleef word. Dit is geen ontologiese gegewe nie, maar 'n ontmoeting in die geloof. Christus as Spreker van God se spreke realiseer sy teenwoordigheid en dit word Woord van God.

Gert Pelser (1989:444) problematiseer die saak van God as handelende subjek. Hoewel die Bybel beskou word as die
Woord van God en dit as vooronderstelling geld, is die menslike aspek daarvan nie mis te kyk nie. Die menslike getuienis in die Bybel is die neerslag van menslike geloofsverstaan, waarvan die gelowiges in Bybelse tye geglo het die selfbetuiging van God aan hulle was. Dit het oor 'n lang periode plaasgevind en onder verskillende omstandighede, sodat dit ook as histories bepaald beskou kan word. Die Bybel verteenwoordig verskillende voorbeelde van geloofsverstaan, wat ook verband hou met herinterpretasie met die oog op toepassing in andersoortige kontekste. Die Bybel verteenwoordig soms verskillende interpretasies van dieselfde gebeure of handelinge van God, waarvan die verskeidenheid dikwels onharmoniseerbaar en selfs teenoorstaande of teenstrydig is. Die tendensieusiteit en polemiese gerigtheid van een teologiese standpunt in die Bybel grens homself soms duidelik af teen 'n ander standpunt in die Bybel, soms binne dieselfde sosio-historiese konteks. Voorbeelde van wat beskou kon word as teologiese ontwikkeling van ' $n$ bepaalde tradisie is nie noodwendig 'n legitieme uitbouing daarvan nie, maar dikwels eerder 'n verarming of afwyking daarvan. Die Bybel blyk inhoudelik dikwels nie enig in sy soort te wees nie, omdat daar in die Bybel elemente van ander tekste opgeneem is. Die redaksie van Bybelse dokumente en gepaardgaande vrae oor eenheid en integriteit van bepaalde geskrifte, sowel as interpolasies en glosses problematiseer die saak verder. Daarmee saam akkommodeer die Bybel 'n verskeidenheid van teologieë. Dit alles in ag genome, is Barth se siening van God as auctor primarius teologies ontoereikend. Hierdie gevolgtrekking word verder bevestig deur die insig dat betekenis nie eensydig deur die teks gegenereer word nie, maar in 'n hermeneutiese sirkelproses, in die wisselwerking tussen teks en eksegeet. In hierdie proses is vooronderstellings onontkenbaar en belangrik, ten spyte daarvan dat die teks as subjek van kommunikasie voorrang het. Die gevolglike inherente meerduidigheid van tekste bring mee dat daar nie iets is soos die betekenis van 'n teks nie, asof dit eens en vir altyd vasgestel kan word nie. Die geskiedenis van die resepsie van tekste bevestig dit. Tyd, omstandighede en lesers het telkens 'n ander verstaan van tekste tot gevolg gehad. Elke verstaan word streng gesproke 'n nuwe teks (Pelser 1989:446-447).

\section{Openbaring}

Barth meen die Bybel spreek net een Woord: Jesus Christus. In daardie sin getuig die Bybel van die Openbaring (Van Zyl 1944:126). Daarom is die Bybel niks anders as die Selfopenbaring van God nie. Hierdie woord is altyd tegelyk openbaring en verhulling. Openbaring is vir Barth altyd indirek, want dit is 'n teken of sakrament van God. Die Bybel is derhalwe 'n teken van 'n teken, die profetiese en apostoliese getuienis van die primêre teken, Jesus Christus (Buitendag 2008:1138).

God openbaar nie iets van God nie maar God sélf; nie iets van sy wese soos net 'n segment nie, maar eerder soos 'n sektor wat tot by die kern strek. Dit is asof ons God in die hart kyk. Die openbaring is altyd God se Selfbekendmaking 
en nie ' $n$ habitus of 'n geopenbaardheid nie. Die waarheid wat openbaar word is daarom 'n Persoon (Buitendag 2008: 1135-1136). Dit wil egter oor die geheel van Barth se openbaringsverstaan lyk of sy openbaringsbegrip 'n persoonlike credo was wat hy verabsoluteer en ontwikkel het tot ' $n$ indrukwekkende dogmatiese paradigma. So het Barth ten prooi geval van die sielkundige subjektiwisme wat hy juis wou vermy (Buitendag 2008:1136-1137, met verwysing na James Barr en Danie Veldsman). Openbaring as begrip is polivalent en kan daarom nie sonder meer semanties ingeperk word nie. Die polivalensie van die begrip 'openbaring' maak dit'n problematiese raam vir Skrifverstaan en dui die eensydige aard van Barth se gebruik daarvan aan. Die begrip 'openbaring' dien nie meer die debat nie en is hoogstens in hibriede vorm teologies bruikbaar (Buitendag 2008:1148).

Luther het egter die begrip 'openbaring' gedekonstrueer. Hy gebruik 'openbaring' om van onder af oor ons verhouding met God na te dink. Luther verstaan 'openbaring' konsekwent in terme van die kom en weerkoms van Christus. God openbaar Homself sub contrario aan die kruis. In Christus is die Deus absconditus tegelyk Deus revelatus. Om alleen maar te glo is wat nou vir die mens oorbly. So is openbaring by Luther geen elitistiese kennis by gelowiges nie, maar vervang geloof openbaring in die tegniese sin van die woord (Buitendag 2008:1139-1140).

'Openbaring' kan selfs verder gedekonstrueer word (Buitendag 2008:1143, met verwysing na Ricoeur). God se transendensie is die interne referent van die geloofsdiskoers en staan dus nie uitgesluit daarvan nie. Openbaring kan daarom nie geverifieer of gefalsifieer word nie, maar word gemanifesteer. Die poëtiese funksie verberg 'n dimensie van die openbaring, naamlik waar openbaring verstaan word in 'n nie-religieuse, nie-teïsistiese en nie-Bybelse sin, maar tog resoneer met een of ander aspek van die openbaring. Die wêreld waarna die teks verwys, bestaan nie agter die teks nie, maar is 'n geprojekteerde wêreld voor die teks in terme van die belydenis van die subjek. Sodoende word openbaring iets wat die teks teweegbring en dit vir die verbeelding moontlik maak om die werklikheid te refigureer (Buitendag 2008:1143).

\section{Geloof}

Die Bybel word vir Barth net in die geloof Woord van God vir ons, nie so dat geloof die Woord vasstel en besit nie, maar omdat dit ons aangryp as God se spreke tot ons en geloof skep (Van Zyl 1944:131). Geloof is die gevolg van die kerugma (Van Aarde 2004:511). Geloof is nie eiemagtig nie maar deur God gemagtigde erkenning, wete, aanhoor, spreke, denke en dade. Die voorhande wees van die Bybel is nog geen bewys dat dit Woord van God is nie. Dit kan alleen as wonder gebeur. Die Bybel is daarom geen orakelboek nie, geen orgaan van onmiddellike mededeling nie. Die menslike aard van die Bybel verhul die Goddelike aard daarvan, wat slegs onthul word met 'n wonder van God. Die Woord van God bly dus sy geheimenis (Van Zyl 1944:131). God kom tot spreke in Christus. Dit bly die ononderhandelbare meta- narratief van die kerk. Geloof is die sine qua non om die Skrif in hierdie lig te lees. Die erkenning dat Jesus die Christus is, is die regeneratio wat die Gees van God bewerk. Dit manifesteer as konfrontasie wat tegelyk disoriënteer en heroriënteer, sodat die appèl tot bekering en versoening altyd in Skrifverstaan gehoor en nagestreef moet word (Buitendag 2008).

Waar die wonder gebeur dat die Woord van God geglo word, bewerk die Heilige Gees dit. Alleen in geloof word die Woord van God verneem. Die Gees aktualiseer dus die Woord en skep geloof. Die Bybel is daarom geen gewone boek nie. Dit bevat die getuienis van besondere mense wat deur die Gees die openbaring van God gesien en gehoor het, en is daarom normatief vir die Kerk. Die Kerk wag op die spreke van God in haar besigwees met getroue eksegese van die Bybel. Die Kerk kan egter nie vasstel en bepaal waar God se spreke is en waar nie, maar bid dat die Bybel deur die Heilige Gees en God se vrye genade weer God se Woord aan ons sal word (Van Zyl 1944:131-132). Daarom stel Barth onomwonde dat niks anders in die kerk staan op dieselfde vlak van pietas [objek van vroomheid] of reverentia [objek van eerbied] as die Bybelse kerugma nie (Van Aarde 2012).

Die Bybel is volgens Barth nie sonder meer herkenbaar as Woord van God nie. Oor die Bybel kan ons net sê dat ons onthou dat ons soms die Woord van God daaruit verneem het, dat die Kerk in die geheel daarvan God se Woord gehoor het en dat ons daarom verwag om weer God se Woord op enige plek in die Bybel te verneem. God se Woord is in die hele Bybel, maar sonder die Heilige Gees kan dit nie vir ons Woord van God word nie, daarom moet die Kerk bid dat God uit vrye genade weer die Bybel Woord van God vir ons sal maak (Van Zyl 1944:132-133). Waar die wonder gebeur, is dit 'n dinamiese gebeure, wat geloof wek en instemming met God se aanspraak betuig (Geyser 1961:302). Die waarheid van die Skrif kan alleen geken word deur geloof as verhouding met God in Christus (Van Aarde \& Geyser 2004:17). Die verstaan van die Bybel is daarom nie uitgelewer aan die willekeur van eksegete nie, omdat die Gees die teks se eintlike verstaanbaarmaker is, hoewel sy werk by die verstaan van die teks net so onnaspeurbaar is as by die ontstaan daarvan (Pelser 1989:447).

Barth se Skrifbeskouing word saamgevat in drie woorde: God, genade, geloof. Deur genade alleen kan ons glo en God in die Bybel leer ken. God bly egter vir ons grotendeels onbekend. Die genade is dat, hoewel ons God nie werklik ken nie, God óns ken. Vir Barth is die Bybel daarom nie menslike gedagtes oor God nie, maar God se gedagtes oor mense. Die inhoud van die Bybel is dus God, maar oor hierdie inhoud kan ons mense maar net stamel. God is groter en meer omvangryk as wat mense kan dink of droom. Die Bybel praat oor hierdie God en is daarom die lewenskrag van die Kerk. Die Kerk se trou aan God is dus geleë in ons trou aan die Bybel (Van Zyl 1944:134). Oor die menslike en Goddelike spreke het daar verruiming gekom, veral oor die aard van menslike spreke oor God. Van Aarde (1995:41) benader die Bybelse dokumente vanuit Bultmann 
se dialektiese gedagte van die voorlopigheid van ons spreke oor God. Ten spyte van God se bekendmaking in die Bybel kan ons God nie sodanig ken dat ons dit kan verwoord in 'n reeks proposisies of dogmas nie. Dit is so omdat alle spreke oor God analogiese spreke is. Mense praat oor die gansandere God na aanleiding van hulle eie bekende menslike begrippe. Die Bybel bly die 'klassieke en gesagvolle getuienis van die saligheid', maar is tegelyk getuienis van metaforiese spreke. Tog is dit ook spreke uit God, Woordgebeure en dinamiese openbaring as gebeure, en nie' $n$ 'geopenbaardheid' nie (Van Aarde 1995:32, 42).

Die verhouding tussen die Bybel en die kerk is vir Barth 'n gegewe wat vergelyk kan word met die verhouding tussen kinders en hulle moeder. Wanneer kinders moet verduidelik waarom 'n spesifieke vrou hulle moeder is, kan dit nie verduidelik word anders as om herhaaldelik net sê dat dit so is nie (Van Aarde 2012).

\section{Inspirasie}

Die Bybelskrywers was volgens Barth nie geïnspireer of uitsonderlik begaafd nie. Hulle woorde word geglo vanweë die inhoud van hulle spreke oor God waartoe hulle geroep is. Barth verwerp alle destyds bestaande inspirasieleringe. Die geïnspireerdheid van die Bybel word verwerp. Die Bybel is nie 'n heilige objek wat verafgod moet word en tussen mense en God staan nie. Die Woord van God is gebeure, lewende verkondiging soos met die prediking, sakramente en die lewe van die Kerk as liggaam van Christus (Van Zyl 1944: 127-128). Om te glo aan inspirasie is om te glo dat die Bybel God se Woord is. Dit kom neer op die erkenning van God se soewereiniteit om so tot mense te spreek. Inspirasie kan dus nie staties wees nie, maar gedurige handeling van die genadige God wat die Bybel opnuut vir ons sy Woord laat word. Wanneer dit gebeur val God se Woord en die mensewoord van die Bybelse getuie saam. Die falende en fouterende mensewoorde word deur God se genade alleen geheilig en geregverdig. Barth se verstaan van inspirasie kom in hierdie opsig neer op 'n woordelikse inspirasie, maar dan nie so dat die mensewoorde onfeilbaar word in terme van taalkunde, historiese of teologiese karakter as mensewoord nie. Die falende en feilbare mensewoorde word deur God in diens geneem ondanks die feilbaarheid daarvan en tot Woord van God gemaak (Van Zyl 1944:132-134).

Andries van Aarde stem hiermee saam, maar nuanseer dit 'n bietjie anders. Vir hom aanvaar gelowiges die Bybel as geloofsboek, nie omdat die kerk 'n formele inspirasieleer het nie, maar omdat die Bybel ontstaan het uit die kerugma en tot kerugma lei, bestudeer word ter wille van kerugma en gelees word met die oog op outentisiteit van gelowiges. Wat erken moet word is dus dat die Skrif op hierdie indirekte wyses na ons toe kom en, ten spyte van feilbaarheid en foute, die essensiële getuienis oor Christus bied (Van Aarde 2004:510-511). Met verwysing na Schleiermacher verduidelik Van Aarde dat inspirasie nie net te maak het met die oorspronklike bekendmaking van Christus nie, maar te make het met die geheel van God se handelinge deur die Gees.
Dit sluit die geheel van die ontstaansprosesse van die Bybelse dokumente in, sowel as die totstandkoming van die kanon en uiteindelik die Bybel, maar ook voortgaan in die verkondiging as uitleg (soos Barth ook sê) en die wek en versterk van geloof daardeur. Die Bybel propageer nie menslike ideale nie en ook nie goeie etiese reëls nie, maar die waarheid van die evangelie van versoening wat 'n appèl tot hoorders rig. God inspireer verkondigers en deur hulle woorde word ander deur God geïnspireer om te glo. Hoedat hulle die verkondiging as Woord van God aanvaar, kan hulle self nie verklaar nie. Hierdie sirkelproses staan bekend as die 'selfgeloofwaardigheid' (outopistie) van die Skrif (Van Aarde 2004:511-512).

\section{Gesag van die Bybel}

Die gesag van die Bybel is vir Barth nie geleë in die kanon as lys gesaghebbende boeke nie, maar in die saak waarna verwys word, naamlik die openbaring van God in Christus Jesus (Van Zyl 1944:134). Hervormde teologie het egter altyd duidelik onderskei tussen die normerende gesag van die Skrif (norma normans) en die ondergeskikte, genormeerde gesag van die belydenisskrifte (norma normata). Die belydenisskrifte word net soos die Bybelse tekste nie as tydlose geskrifte beskou nie, maar in terme van hulle historiese omstandighede uitgelê (Breytenbach 1989:334). Daarom is daar gepraat van die belydenisskrifte as simbole van die kerk (Engelbrecht 1944a; 1944b; 1944c) en kon verskille tussen belydenisskrifte aangetoon word (Engelbrecht 1989).

Van Aarde stem met Barth saam dat die gesag van die Skrif verband hou met die kerugma eerder as met ' $n$ formele inspirasieleer. Die Bybel het ontstaan uit die kerugma en lei weer tot kerugma. Die Skrif is nie op sigself kerugma nie en daarom ook nie die grond vir geloof in Christus nie. Geloof is eerder die grond van die gesag van die Skrif. Dit is nie die Skrif wat geloof wek nie, maar die kerugma (Van Aarde 2004:510).

Die gesag van die Bybelse dokumente wat lesers met die kerugma konfronteer, moet telkens weer bevestig word in 'n dinamiese proses waar die Bybel in die geloofsgemeenskap gelees word op so 'n manier dat die Bybel anderkant homself na God wys. Hierdie proses staan bekend as kontekstuele funksionaliteit en word medebepaal deur die kulturele konteks, omdat die betrokke geloofsgemeenskap se inhoudsvulling van die begrip kanon afhang van wat hulle as kanon gebruik en die funksie wat hulle daaraan toeken (Venter 1998:506-507).

Hoewel die Reformatore gepoog het om juis na die gesaghebbende of oudste teks te soek as toepassing van die ad fontes en sola scriptura beginsels, het die verbinding van die kanon aan een gefikseerde teks in die ortodoksisme ontaard in sienings oor foutloosheid en inspirasie. Dit het weer in beide gevalle 'n bepalende effek gehad op Skrifbeskouing en teologie. Tekskritiese navorsing het egter aangedui dat dit nie moontlik is om een bepaalde vorm 
van die teks uit te lig as die kanon of oorspronklike teks nie. Daar moet rekening gehou word met 'n pluriformiteit van tekste weens die veelvoud van manuskripte uit verskillende tekstradisies en die gevolglike groot aantal variante lesings wat voorkom (Venter 1998:507-509). Die geweldige hoeveelheid tekste en teksvariasies bevestig dat kanon nie net op tekstuele vlak as lys van boeke teoreties gewerk het as norma normata van geloofsgemeenskappe nie. Sosiogodsdienstige faktore het bepaal hoe ' $n$ bepaalde vorm van die tradisie sou lyk. Dit was dus 'n funksionele kanonisiteit. Dit bepaal nie alleen die tekstuele oorlewering nie, maar ook hoe die tekste in die bepaalde geloofsgemeenskap as kanon gebruik sou word. Dit gaan dus oor 'n lewende tradisie wat telkens by nuwe omstandighede aangepas is en nie as fossielagtige gefikseerde kanons nie (Venter 1998:511-512).

Hierdie aspekte, sowel as meer onlangse kritiek op die androsentriese formulerings in die Bybelse tekste uit feministiese kringe, asook uit die lesersgeoriënteerde benadering, het die kulturele bepaaldheid beklemtoon. Dit het meegebring dat die tekste al meer verstaan is as menslike produk wat kultureel bepaal en begrens is. Daarmee is die 'gesag' van die Bybel bevraagteken. Daarop kan egter net geantwoord word met die belydenis dat God juis nie anders as deur mensewoorde na mense toe kom nie (Venter 1998:506, 511-512).

In die huidige tyd is die gebruik van die Bybel as kanon ook nie staties nie en lesers word steeds gedwing om vanuit hulle eie sosio-kulturele konteks opnuut 'n metafoor oor God te produseer wat vir hulle geldig is binne hulle leefwêreld. Dit is belangrik om raak te sien dat die kanon dus nie in die Bybel geleë is nie, maar in die gelowige gebruik van die Bybel (Venter 1998:525). Geloof is die sine qua non vir die lees en verstaan van die Skrif op so 'n wyse dat God in Jesus Christus opnuut tot spreke kom (Buitendag 2008:1149).

\section{Die verhouding Ou en Nuwe Testament}

Volgens Barth spreek die Ou Testament profeties oor Christus se koms en die Nuwe Testament getuig van die vervulling daarvan (Van Zyl 1944:124-125). Die belofte-vervulling skema is egter nie ' $n$ bevredigende antwoord op die vraag na die verhouding $\mathrm{Ou}$ en Nuwe Testament nie. Een van die redes daarvoor is die verskeidenheid van dokumente en teologieë teenwoordig in die Bybel, sodat daar nie eens sprake van 'n eenheid binne die Ou of Nuwe Testamente self is nie, wat nog tussen die twee Testamente. In hierdie verband kan hoogstens gepraat word van eenheid in verskeidenheid, en dikwels dring die verskeidenheid hom sterker op die voorgrond as die eenheid. Verskeidenheid hoef egter nie negatief beoordeel te word nie, maar kan beskou word as die dinamiek van God se handelinge en mense se antwoorde daarop (Pelser 1989:447). Tog is dit opvallend dat die Nuwe Testament die Christusgebeure grotendeels verstaan vanuit die $\mathrm{Ou}$ Testament as verwysingsraamwerk.

Daar was verskeie pogings om 'n samehang tussen die twee Testamente aan te dui, wat verband hou met kanonbeskouing, soos byvoorbeeld die kanon in die kanon. Daar kan drie verskillende gestaltes van die kanon in die kanon onderskei word (Pelser 1988:394):

- fisiese verkorting van die kanon aan die hand van 'n beginsel, soos Luther se Sachkritik met sy Was Christum treibet-beginsel

- ordening van die geskrifte na aanleiding van 'n kanonieke sentrum met konsentriese sirkels rondom, van meer na minder kanoniek. Die kanon bly onveranderd.

- daadwerklike soeke na 'n kernsaak (Sachmitte) in die kanon as maatstaf. Vir die Nuwe Testament sou dit kon wees die Pauliniese evangelie, of die verkondiging van Jesus, Paulus en die Johannesevangelie. Latere geskrifte met spore van Frühkatholizismus sou uitgesluit wees van gebruik omdat hulle nie draers van die Sachmitte is nie.

Pelser, saam met Sanders, neem as vertrekpunt dat die kanon pluriform is. Dit verwoord die feit dat daar in die Bybel 'n verskeidenheid van teologieë, sowel as ontwikkelinge van hierdie teologieë voorkom. Indien hulle versoenbaar sou wees of beskou word om almal gelyke impak op die teologie en geloof sou hê (soos by Brevard Childs), sou daar geen hermeneutiese probleem wees nie. Die verskeidenheid is egter nie versoenbaar nie, die verskillende teologieë kan ook nie op gelyke voet naas mekaar gehandhaaf word nie en sekere paradokse bly problematies. Dit geld nie net randsake nie, maar sake van sentrale belang. Pelser meen grootskaalse harmonisering is prinsipieel onaanvaarbaar en beskou dit as utopiese wensdenkery. Die kerklike praktyk wys harmonisering is nooit werklik met sukses deurgevoer nie. Die pluriformiteit van die kanon leen hom tot pluriforme aanwending. Dit verklaar die verskillende kerke en sektariese strominge weens verskillende interpretasies, aksente en ideologiese seleksie van wat beskou sou word as bepaalde kerntekste wat as hermeneutiese vooronderstelling dien. So bevestig die praktyk Käsemann se gevolgtrekking oor die kanon, naamlik dat die kanon eerder die verskeidenheid van denominasies begrond as die eenheid van die kerk (Pelser 1988:389-391).

Die verskeidenheid in die kanon kan toegskryf word aan drie sake (Pelser 1988:392):

- Verskillende hermeneutiese pogings in die Nuwe Testament om die Jesus-saak te verstaan met verskillende aksente oor wat geglo moet word.

- Ontwikkeling het plaasgevind binne die verskillende verstaanspogings. Watter stadium van ontwikkeling sou geldend wees?

- Kanonisering omsluit die verskeidenheid met sy teenstrydighede formeel in een geheel.

Dit is so omdat daar in die eerste eeu al geen normatiewe vorm van Christendom bestaan het nie. Eerder as 'n suiwer of ortodokse Christendom, was daar gewoon verskillende vorme van Christengroepe wat gekompeteer het vir volgelinge. Daar was teologies geen algemeen geldende norm vir kanonvorming nie (Pelser 1988:391-393). 
Dat sekere Bybelse geskrifte in die kanon 'n groter invloed as ander uitgeoefen het om die kerk se geloof te vorm, kan aanvaar word (Van Aarde 2001:156). Die gevaar van 'n gemaklikheid met 'n kanon in die kanon kom neer op reduksionisme met die gevolglike neiging tot intoleransie jeens die diversiteit van geloofsuitinge aanwesig binne die kanon (Van Aarde 2001:157). Die diversiteit in die Bybel het te make met die verskeidenheid van literatuursoorte, tradisies en boodskappe. Eerder as te streef na harmonisasie behoort die diversiteit waardeer te word as getuienis van die reikwydte van God se liefde, wat nie deur sisteme ingeperk word nie. Tog bly die kerugma die wesenlike eenheid van die Bybel (Van Aarde 2004:513). Kanonisiteit is derhalwe nie so wesenlik as die bediening van die versoening nie en is hoogstens 'n saak van kerklike belydenis (Van Aarde 2012).

Nog 'n voorbeeld is die gedagte van 'n kanon agter die kanon, soos deur Andries van Aarde voorgestel. Vir Van Aarde (2001:157) is die diversiteit van geloofsuitinge oor die Jesusgebeure in die kanon nie problematies nie, maar wel wanneer daar geloofsuitinge na vore kom wat 'n vervreemding van die Jesussaak meebring. In hierdie verband is hy dit eens met Luther se kanon in die kanon, wat Jesus in die voorgrond geplaas het en die Jesusgebeure as God se regverdiging as maatstaf gebruik het.

Van Aarde (2001:157-158) verkies egter om saam met Willi Marxen te praat van die kanon agter die kanon, ${ }^{6}$ eerder as kanon in die kanon. Met 'agter' word 'n materiële en historiese prioriteit aangedui. Van Aarde verwys na Luther se 'Christus predigten und treiben' maatstaf, wat vir Luther die aanduiding van apostolisiteit was. Vir beide Luther en Van Aarde is hierdie maatstaf die Pauliniese verkondiging van God se regverdiging van sondaars deur geloof in die Jesusgebeure alleen (vgl. Rom 1:7). Dit strook met Pannenberg se oordeel dat Luther se Sache der Schrift, die persoon en geskiedenis van Jesus nie meer vir ons historiese bewussyn in die teks geleë is nie, maar '... muß hinter ihnen erschlossen werden (Panneberg in Buitendag 2008:1141)’.

Hierdie uitgangspunt van Van Aarde is van groot belang vir die Hervormde Skrifbeskouing. Hiermee word aangedui dat dit nie die kanon is wat vir die kerk as primêre gesag geld nie, maar die Jesus-saak, Paulinies opgesom as die regverdiging deur geloof alleen. Saam met Willi Marxen meen Van Aarde tereg dat die Bybel nie in die plek van Jesus as 'die' openbaring behoort te staan nie, want die Christendom is 'n godsdiens gebaseer op ' $n$ historiese persoon en nie ' $n$ boek nie. Hy stem met David Tracy saam dat die Christendom 'n godsdiens van die opgestane Jesus is. Die Jesusgebeure het spore in die Nuwe Testament gelaat, en via hierdie tekste moet daar teruggevra word na die normerende kodifisering van die Jesusgebeure. Die soeke na die normatiewe Jesusgebeure via die tekste dui op die tradisie-aard, asook die historiesoorgelewerdheid van die Christelike verkondiging. Vir Christene is die Jesusgebeure die gebeure van God se koms na mense. Dit sluit nie die Ou-Testamentiese geskrifte uit nie.

6.Van Aarde beskou Luther se benadering nie as kanon in die kanon nie.
Van Aarde (2012) bring dit in verband met wat Pieter Venter (1998:527) die goeie nuus van Jesaja (40:9) noem. In die verhale oor Jesus ontmoet gelowiges God steeds. Deur hierdie interaksie met Jesus word God dus God vir die mense. Hierdie interaksie waarmee God verstaan word as God vir mense is die Jesus-saak, wat begin het met die voorPase Jesus en voortgesit word in die na-Pase verkondiging van Jesus, wat wyer loop as die eerste eeu en steeds voortgaan. Hoewel Christene van God se koms na mense verneem deur die Bybelse tekste, is dit nie die Bybel nie maar God as die komende wat die primêre gesag in die kerk is (Van Aarde 2001:148-149). Danksy histories-kritiese ondersoek kon Nuwe-Testamentici tot 'n groot mate die waarskynlike woorde en dade van Jesus vasstel, asook die geloofsuitinge van Jesus se volgelinge, wat gesamentlik opgeneem is in die kerugma naspeur en die wesenlike Jesus-saak dekodeer, sodat gelowiges vandag steeds kan deelneem aan die Jesussaak (Van Aarde 2001:150).

Pelser wys dat die identifisering van so 'n kanonkriterium 'n onvermydelike sirkelgang bevat weens teenstrydighede in die Nuwe Testament: die kriterium word aan die Nuwe Testament ontleen en dan word die Nuwe Testament krities daaraan getoets. Hoe paradoksaal dit ook al mag klink, respekteer hierdie werkswyse die kanon op sy grondigste en op gepaste wyse omdat dit in die kanon as formele identiteit slegs relatief geïnteresseerd is. Hy stel dit verder dat die keuse vir 'n Sachmitte onvermydelik is en bepaal word deur die diversiteit in die Nuwe Testament, hermeneutiese vooronderstellings en kenteorie, en 'n nuwe werklikheidsverstaan wat deur veranderde omstandighede meegebring word. So 'n kriterium of hermeneutiese sleutel kan egter nooit eens en vir altyd absoluut geldig wees nie. Die kontrole van so 'n kanonbeginsel word gevind in teologies-wetenskaplike diskussie daaroor. Die kanon behoort egter nie verklein te word nie omdat ons die hele kanon nodig het om die kanon in/agter die kanon te onderskei en eensydigheid te voorkom (Pelser 1988: 396-401).

Pieter Venter meen egter dat 'n kanon in die kanon neerkom op dekanonisering van die kanon. Kanonisering kan as hipersentrisme beskryf word, wat in 'n dialektiese verhouding staan tot die hiposentrisme van dekanonisering. Hy sien raak dat alhoewel leerstukke kan verouder en gedekanoniseer kan word, dit nie met die Bybel as geheel gebeur nie. Dit is belangrik om raak te sien dat by dekanonisering die probleem nie by die inhoud lê nie, maar by die status wat 'n gemeenskap aan 'n bepaalde kanon soos die Bybel toeken en hoe hulle hierdie status formuleer. Die algemene konsepte van kanon, kanonisiteit en kanonisering impliseer dat daar nie iets soos die kanon is nie. Daar is kanons, elk met hulle eie normatiewe aansprake en hulle staan meestal in opposisie met mekaar. Selfs profane tekste of narratiewe kan die rol van 'n godsdienstige kanon oorneem en van sy posisie stroop. Dekanonisering beteken dan die geleidelike proses waardeur 'n bestaande kanon ongeldig gemaak word. Aan die ander kant is dit ook so dat 'n gekanoniseerde teks noodwendig 'n dialektiese 
dekanoniseringsproses veroorsaak. Om in momentum te bly moet die leemtes met betrekking tot die bestaande kanon gevul word deur byvoorbeeld interpretasie en nuwe kontekstualiserings (Venter 2006:1385-1388).

\section{Ten slotte}

Die eiesoortige Barthiaanse tipe Skrifbeskouing wat in die Hervormde teologie ontwikkel het, is een van die kosbare winspunte van die Hervormde teologie. Natuurlik strek die wortels daarvan veel dieper as Barth se Skrifbeskouing na ons Reformatoriese erfenis. Daarom is dit betreurenswaardig dat sommige Hervormde teoloë en predikante on-Reformatoriese outoritêre fundamentalistiese of fondamentalistiese Skrifbeskouings huldig wat die Barthiaanse Skrifbeskouing bedreig, en daarmee saam die groei en diversiteit van die Hervormde teologie aan bande lê (Van Eck 2008:1159).

\section{Erkenning \\ Mededingende belange}

Die outeur verklaar dat sy geen finansiële of persoonlike verbintenis het met enige party wat haar nadelig kon beïnvloed het in die skryf van hierdie artikel nie.

\section{Literatuurvewysings}

Breytenbach, A.P.B., 1989, Enkele aspekte van Skrifbeskouing, HTS Teologiese Studies 45(2), 328-334. https://doi.org/10.4102/hts.v45i2.2264

Buitendag, J., 2008, 'God met ons'-gelowig nagedink oor die Skrif, HTS Teologiese Studies/Theological Studies 64(3), 1131-1154. https://doi.org/10.4102/hts. v64i3.67

Engelbrecht, B.J., 1989, " $n$ Vergelyking tussen die teologie van die Nederlandse Geloofsbelydenis en die Heidelbergse Kategismus', HTS Teologiese Studies 45(3), 626-644. https://doi.org/10.4102/hts.v45i3.2312

Engelbrecht, S.P., 1944a, 'Die Nederlandse Geloofsbelydenis as simboliese dokument Deel I', HTS Teologiese Studies/Theological Studies 1(2), 80-95. https://doi. org/10.4102/hts.v1i 2.3314
Engelbrecht, S.P., 1944b, 'Die Nederlandse Geloofsbelydenis as simboliese dokument Deel II', HTS Teologiese Studies/Theological Studies 1(3), 109-114. https://doi. org/10.4102/hts.v1i3.3318

Engelbrecht, S.P., 1944c, 'Die Heidelbergse Kategismus as kerklike simboliese geskrif', HTS Teologiese Studies/Theological Studies 1(4), 160-173. https://doi. org/10.4102/hts.v1i4.3327

Gemser, B., 1944, 'Maartin Luther oor hoe noodsaaklik dit is om Latyn, Grieks en Hebreeus te leer', HTS Teologiese Studies/Theological Studies 1(4), 178-186. https://doi.org/10.4102/hts.v1i4.3328

Geyser, A.S., 1961, 'Logos en ideologia. Woord en skynwoord', HTS Teologiese Studies 16(4), 300-307. https://doi.org/10.4102/hts.v16i4.3817

Geyser, P.A., 1989, 'Prof dr F J van Zyl se Skrifbeskouing', HTS Teologiese Studies/ Theological Studies 45(2), 253-262. https://doi.org/10.4102/hts.v45i2.2254

Geyser, P.A., 2000, 'Hermeneutiese uitgangspunte in historiese-Jesus navorsing, Dee 1: Sosiaal-wetenskaplike vooronderstellings', HTS Teologiese Studies/THeological Studies 56(2\&3), 527-548. https://doi.org/10.4102/hts.v56i2/3.1752

Pelser, G.M.M., 1988, 'Die kanon in die kanon as hermeneuties-teologiese probleem' HTS Teologiese Studies/Theological Studies 44(2), 388-403. https://doi. org/10.4102/hts.v44i2.2218

Pelser, G.M.M., 1989, 'Die Bybel aan die universiteit en in die kerk', HTS Teologiese Studies/Theological Studies 45(2), 442-450. https://doi.org/10.4102/hts.v45i2.2287

Van Aarde, A.G., 1995, 'Kerk en Teologie op pad na die derde millennium: Gedagtes oor die kontekstualisering van die dialektiese teologie in 'n plurale samelewing', HTS Teologiese Studoes/Theological Studies 51(1), 39-64.

Van Aarde, A.G., 2001, 'The "cause of Jesus" (Sache Jesu) as the Canon behind the Canon', HTS Teologiese Studies/Theological Studies 57 (1\&2), 148-171.

Van Aarde, A.G., 2004, 'Skrifbeskouing in die lig van Postmoderniteit', HTS Teologiese Studies/Theological Studies 60(1 \& 2), 503-532. https://doi.org/10.4102/hts. v60i1/2.502

Van Aarde, A.G., 2012, 'The use and origin of the (Old and) New Testament as Christianity's canon', HTS Teologiese Studies/Theological Studies 68(1), Art. \#1262, 1-8. https://doi.org/10.4102/hts.68i1.1262

Van Aarde, A.G. \& Dreyer, T.F.J., 2011, 'Die pendule subjektiwiteit-objektiwiteit in die teologie van Theuns Dreyer - 'n dialoog', HTS Teologiese Studies/Theological Studies 67(3), Art. \#1172, 1-11. https://doi.org/10.4102/hts.v67i3.1172

Van Aarde, A.G. \& Geyser, P.A., 2004, 'Om nie te dink bo "wat in die Skrif geskrywe staan nie" - konsistensie en ontwikkeling in die teologie van Piet Geyser', HTS Teologiese Studies/HTS Theological Studies 60(1 \& 2), 7-28. https://doi. org/10.4102/hts.v60i1/2.501

Van der Merwe, P.J., 1989, 'Prof dr F J van Zyl as mens, kerkman en godsdiensfilosoof' HTS Teologiese Studies/Theological Studies 45(2), 231-252. https://doi. org/10.4102/hts.v45i2.2253

Van Eck, E., 2008, 'Een teks - meerdere betekenisse: Hoe lees ons die Bybel?', HTS Teologiese Studies/Theological Studies 64(3), 1155-1185. https://doi. org/10.4102/hts.v64i3.82

Van Zyl, F.J., 1944, 'Die Skrifbeskouing van Karl Barth', HTS Teologiese Studies/ Theological Studies 1(3), 124-135. https://doi.org/10.4102/hts.v1i3.3320

Venter, P.M., 1998, 'Wat beteken "kanon" vandag?', HTS Teologiese Studies/ Theological Studies 54(3 \& 4), 505-528. https://doi.org/10.4102/hts.v54i3/4.1424

Venter, P.M., 2006, 'Kanon: Eenheid en diversiteit', HTS Teologiese Studies/Theological Studies 62(4), 1369-1393. https://doi.org/10.4102/hts.v62i4.394 